\begin{tabular}{|l|l|l||}
\hline \multicolumn{2}{|c|}{ PublisherInfo } \\
\hline \hline PublisherName & $:$ & BioMed Central \\
\hline \hline PublisherLocation & $:$ & London \\
\hline \hline PublisherImprintName & $:$ & BioMed Central \\
\hline \hline
\end{tabular}

\title{
Phage tropism
}

\begin{tabular}{|l|c|l||}
\hline \multicolumn{2}{|c|}{ ArticleInfo } \\
\hline \hline ArticleID & $:$ & 4426 \\
\hline \hline ArticleDOI & $:$ & $10.1186 /$ gb-spotlight-20020320-01 \\
\hline \hline ArticleCitationID & $:$ & spotlight-20020320-01 \\
\hline \hline ArticleSequenceNumber & $:$ & 92 \\
\hline \hline ArticleCategory & $:$ & Research news \\
\hline ArticleFirstPage & $:$ & 1 \\
\hline \hline ArticleLastPage & $:$ & 2 \\
\hline \hline & & RegistrationDate : 2002-3-20 \\
\hline ArticleHistory & $:$ & OnlineDate \\
\hline \hline ArticleCopyright & $:$ & BioMed Central Ltd2002-3-20 \\
\hline \hline ArticleGrants & $:$ & \\
\hline \hline ArticleContext & $:$ & 130593311 \\
\hline \hline
\end{tabular}




\section{Jonathan B Weitzman}

Email: jonathanweitzman@hotmail.com

Certain Bordetella bacteria exist in two phases - Bvg+ is characterized by the expression of virulence genes and respiratory tract colonization, while the Bvg- phase is adapted for ex vivo growth when virulence genes are silenced. In the March 15 Science Liu et al. from the University of California in Los Angeles, describe how bacteriophages target specific bacterial phases (Science 2002, 295:2091-2094). They found that the bacteriophage BPP-1 (for Bvg plus tropic phage-1) had a tropism for the Bvg+ phase bacteria. They identified the prn gene, encoding the adhesin pertactin, as essential for tropism, and were able to isolate bacteriophage variants with different tropisms, implying a mechanism of tropic switching. They then looked at tropic variants and noticed a 134 bp repeat sequence within the $m t d$ (major tropism determinant) locus, which is repeated in an adjacent brt locus encoding a Bordetella reverse transcriptase enzyme. The brt repeat and the brt enzyme affected sequence variation of the $m t d$ repeat. It will be interesting to figure out how variations in these repeat sequences, and the reverse transcriptase, regulate tropic switching, and whether similar scenarios exist for generating genetic variation in other biological systems.

\section{References}

1. In vivo and ex vivo regulation of bacterial virulence gene expression.

2. Science, [http://www.sciencemag.org]

3. University of California in Los Angeles, [http://www.ucla.edu] 